\title{
Comparison of Blood Cholesterol Profiles Before and After The Measurements of Maximum Aerobic Capacity $\left(\mathrm{VO}_{2} \mathrm{max}\right)$
}

\author{
AR. SHADIQIN \\ JPOK-FKIP Lambung Mangkurat University, Banjarbaru
}

\begin{abstract}
This study is aimed to compare the blood cholesterol profile, before and after the measurement of maximum aerobic capacity $\left(\mathrm{VO}_{2} \max \right)$ in the students of Jurusan Pendidikan Olahraga dan Kesehatan (JPOK) pada Fakultas Keguruan dan Ilmu Pendidikan (FKIP) Universitas Lambung Mangkurat Banjarmasin.Variables in this study consist of lipid profiles, including total cholesterol, high density lipoprotein (HDL), low density lipoprotein (LDL), triglyceride (TG) and Maximum Aerobic Capacity $\left(\mathrm{VO}_{2} \mathrm{max}\right)$. The concept of $\mathrm{VO}_{2} \mathrm{max}$ according to Kent ${ }^{(1994: 268)}$ : "maximum oxygen volume consumed per minute to show total work capacity, or volume per minute relative to body weight ( $\mathrm{ml} / \mathrm{kg}$. min)". Operationally, $\mathrm{VO}_{2}$ max referred in this study is the maximum volume of oxygen that can be consumed per minute, as measured at progressive run (Bleep Test). The method used in this study is pre-experimental with one group pretest-posttest design. This design implies that a group of subjects are treated for a specific period and the measurements are taken both pre and post. The results: There are changes in blood cholesterol profile after the measurement of maximum oxygen capacity $\left(\mathrm{VO}_{2} \max \right)$, shown by significant decrease of total cholesterol variable, increased HDL, and decreased LDL. Changes in triglyceridevariable showed no significant decrease despite the statistic differences. Specific HDL sub-class increasing after exercise is a constructive lipoprotein sub-class whereas LDL is destructive lipoproteins sub-class that might damage the body. Therefore, an increase in HDL and decrease in LDL found in this study appears to be advantageous and consequently might alter the risk of coronary heart disease.
\end{abstract}

\section{Keywords: Cholesterol profile, Maximum Aerobic Capacity $\left(\mathrm{VO}_{2} \mathrm{max}\right)$} \section{INTRODUCTION}

Most of busy and dynamic individuals underestimate healthy macro-nutrition requirement and consumed fast-food meals instead, where both quantity and quality is uncontrolled. Metabolically, not all of these options provide healthy responses, and they frequently complain pain in their chest (angina) which is one indicator of increasing cholesterol level (Soeharto I, 2002:108). Any type of medical treatment requires a substantial fund. On the other hand, specific drugs may drastically decrease cholesterol levels, thus became insufficient for the body. Despite of body requirement, abnormal cholesterol level may adversely affect cardiac

$\begin{array}{lll}\text { Correspondence: AR. } & \text { Shadiqin, JPOK-FKIP, } \\ \text { Lambung Mangkurat } & \text { University, } & \text { Banjarbaru, }\end{array}$

performance. Heart serves as a pump in blood circulation, therefore blood cholesterol profiles before and after measurement of maximum aerobic capacity still need to be examined.

Precursor forming steroid hormone that the body need is derived from cholesterol (Vander, Sherman, Luciano, 2001:267; Vella CA, Kravistz L, Jarot JM, 2002:1). Types of these hormones are: cortisol, adrenaline, testosterone, estrogen, etc. Structurally, cholesterol is a required component in the body system. If a person's blood cholesterol is reduced up to 30 percent of the normal range, cell structures disorder possibly to occur (B Sears, 1997:183). High saturated fat diet may increase blood cholesterol concentrations for 15 to $25 \%$. This condition is due to the enhancing fat accumulation in liver which increase KoA-acetyl hepatic cell to produce cholesterol (Gayton \& Hall, 1996:1087). Therefore, one possible way to decrease blood cholesterol concentration is 
diet of low saturated fat and low cholesterol (B Sears, 1997:183). The concept of energy metabolism to maintain cholesterol at normal concentrations is sporadic. This mainly because busy lifestyle and the idea of instant health without particular treatments. Although many individuals perform certain physical activities, presumably they are not suitably programmed. Otherwise, even if such activities are correct, cholesterol concentration remains increase due to the imbalance nutritional factors with energy expenses. Thus, more frequent pains is coming instead of healthy condition as a result of the increasing cholesterol.

Based on the above description, maintenance as well as efforts to reduce blood cholesterol profile that provide healthy responses for each individual are still need to be studied. Increasing cholesterol ingested daily may slightly increase plasma concentrations. However, such increase inhibits 3-hydroxy-3-metilglutaril KoA reductase enzyme (Guyton \& Hall, 1997: 1087) to form endogenous cholesterol. This mechanism plays as an intrinsic feedback control system to prevent an excessive increase of plasma cholesterol concentrations. As a result, plasma cholesterol concentrations usually do not increase or decrease more than $\pm 15 \%$ by changing the amount of cholesterol in the diet, although individual responses differ markedly (Vander, Sherman, Luciano, 2001:610). Most of extra-busy workers tend to ignore this balance mechanism where diet of high saturated fat and cholesterol is preferable shortcut. Expensive medical treatment became a "trend" of consumptive lifestyle in expectation of instant recovery. However, the fact that patients with related complaints were increased and in inverse comparison with per capita income. Therefore, revealing physical performance patterns that is safe, inexpensive and able to maintain blood cholesterol profile is a priority.

The solution of those conditions, there should be a careful assessment of physical activities that are safe and easy as well as favorably effect blood cholesterol concentrations reduction. A specific distance of aerobic run, very popular physical workout, is able to improve physical fitness (EA Dowling, 2001:47). Thus, it is necessary to study their effects on blood cholesterol profile, especially after an individual reaches his/her anaerobic threshold. Consequently, the concept of energy metabolism can be used as a pattern to determine blood cholesterol profile for each individual, without having to go through expensive treatments.

\section{MATERIALS AND METHODS}

Concept of Approach. This study used physiobiologic paradigm with the concept of energy metabolism; the logic is built based on the application of the predominant energy in continuous aerobic physical performance and its impact on health status, reflected in cholesterol profile in the blood.

Type of the Study. This is an experimental study, which aimed to determine the effect of exercise workload (in the form of $\mathrm{VO}_{2} \max$ test) on blood cholesterol profile.

Design of the Study. The design of this study was Pretest-Posttest Only Design (Suryabrata S, 2003:105). Operational data collection is described as the following diagram.

T-1------- BLEEP TEST ---------- T-2

Description: $\mathrm{T}-1=$ Preliminary Test or control data; BLEEP TEST is the Treatment, $\mathrm{T}-2=$ Final Test .

Population, Sample and Analysis Unit. This study used healthy male students as the population, with characteristics; physically and psychologically healthy, age ranged between $20-24$ year-old. The population is derived from students of Jurusan Pendidikan Olahraga \& Kesehatan FKIP Unlam Banjarmasin. Total sample is 12 people.

\section{Sampling Technique}

Twelve qualified students are chosen with systematic random sampling technique. 
Subsequently, assigned both as experimental and control.

\section{Sample Criteria}

Sample criteria in this study are factors that influence research results. Thus, the following factors are defined; general physical status (age, weight, height) and health status.

\section{Unit of Analysis}

The unit of analysis in this study is blood extracted from vein (vena cubiti). This peripheral blood test is based on the fact that observed components through the analysis unit may circulate and recirculate (AR.Shadiqin, 2001:56).

The variables of this study are; dependent variableBleep Test, and cholesterol profile is creterion; control variable: SGOT, SGPT, BUN, and creatinine.

Conceptual Definition of Variables. Cholesterol: A lipid-related compound found in tissue and manufactured in the liver (Kent $M, 1994)$. Blood cholesterol level can be decreased with exercise and dietary fat.

Maximum oxygen volume; Kent $M$ (1994) stated that "maximum aerobic force quantitatively equivalent to the maximum amount of oxygen that can be consumed per unit time during elevating intensity up to exhaustion, expressed as $\mathrm{VO}_{2} \max$ ".
Operational Definition of Variables. Blood cholesterol level is a value that reflects the amount of cholesterol circulating in the blood vessels known through clinical test of analysis unit.

$\mathrm{VO}_{2} \max$ is the maximum amount of oxygen in milliliters, which can be used in one minute per kilogram of body weight, measured through the Bleep Test.

Technique of Data Analysis. The collected data will be analyzed using computer statistical methods (SPSS-18) with $t$-test analysis.

\section{RESULTS}

Description of Data. The data in the following tables is the result of lipid profile measurement consisting of total cholesterol (TK), low density lipoprotein (LDL), high density lipoprotein (HDL), triglyceride (TG) and maximum oxygen volume $\left(\mathrm{VO}_{2} \mathrm{max}\right)$. Measurements were conducted with a clinical chemistry analysis, $\mathrm{VO}_{2} \max$ with the Bleep Test.

The unit of analysis in this research is blood extracted from vein (venous cubiti). Blood examination of the peripheral blood is based on the fact that these components can be detected to mark a variable and can both circulate and recirculate. Prior to hypothesis testing, normality and homogeneity tests of the samples were taken.

Table 1. Measurement results of Lipid Profile before treatment

\begin{tabular}{clcll}
\hline No. & TK & LDL & HDL & TG \\
1 & 208.8 & 149.8 & 45 & 70.2 \\
2 & 117.8 & 98 & 45 & 64.8 \\
3 & 179.2 & 95.9 & 75 & 45.2 \\
4 & 195.2 & 134.9 & 54 & 41.5 \\
5 & 118.6 & 53.6 & 58 & 45 \\
6 & 191.7 & 119.9 & 62 & 49 \\
7 & 174.6 & 113 & 37 & 83 \\
8 & 159.4 & 102.2 & 50 & 36 \\
9 & 100.2 & 44.6 & 49 & 33 \\
10 & 150.2 & 77.4 & 67 & 49 \\
11 & 158.8 & 95.3 & 63 & 75 \\
12 & 173.2 & 90.2 & 75 & 38 \\
Average & 160.64 & 97.5 & 56.67 & 52.47 \\
\hline
\end{tabular}

Description:

No : Number of subjects

TK : Total Cholesterol 
LDL : Low density lipoprotein

HDL : High density lipoprotein

TG : Triglyceride

Tabel 2.Measurement results of $\mathrm{VO}_{2} \max$ and Lipid Profile after treatment

\begin{tabular}{cclcll}
\hline No. & $\mathrm{VO}_{2}$ mak & TK & LDL & HDL & TG \\
\hline 1 & 38.5 & 198 & 144.5 & 48 & 70 \\
2 & 40.1 & 116 & 95 & 46 & 62.5 \\
3 & 38.2 & 167.2 & 90.2 & 72 & 47 \\
4 & 40.2 & 169 & 129 & 60 & 41.2 \\
5 & 40.5 & 117 & 53 & 58 & 45 \\
6 & 39.1 & 176 & 98 & 66 & 48 \\
7 & 41.2 & 174 & 100 & 47 & 71 \\
8 & 39.8 & 155.8 & 100.1 & 54 & 36 \\
9 & 43.2 & 100 & 44 & 50 & 32 \\
10 & 37.5 & 148.5 & 75 & 67 & 47 \\
11 & 40.5 & 139 & 85 & 64 & 71 \\
12 & 38.5 & 158 & 79 & 77 & 39 \\
\hline Average & 39.77 & 151.54 & 91.07 & 59.08 & 50.81 \\
\hline
\end{tabular}

Description:

No : Number of subjects

TK : Total Cholesterol

LDL : Low density lipoprotein

HDL : High density lipoprotein

TG : Trigliseride

Table 3. Result of Normality Test with One-Sample Kolmogorov-Smirnov Test.

\begin{tabular}{|c|c|c|c|c|c|c|c|c|c|}
\hline & & $\begin{array}{l}\text { TK } \\
\text { first }\end{array}$ & $\begin{array}{l}\text { TK } \\
\text { last }\end{array}$ & $\begin{array}{l}\text { LDL } \\
\text { first }\end{array}$ & $\begin{array}{r}\mathrm{LDL} \\
\text { last }\end{array}$ & $\begin{array}{l}\text { HDL } \\
\text { first }\end{array}$ & $\begin{array}{c}\text { HDL } \\
\text { last }\end{array}$ & $\begin{array}{l}\text { TG } \\
\text { first }\end{array}$ & $\begin{array}{l}\text { TG } \\
\text { last }\end{array}$ \\
\hline $\mathrm{N}$ & & 12 & 12 & 12 & 12 & 12 & 12 & 12 & 12 \\
\hline & Mean & 160.642 & 151.542 & 97.900 & 91.067 & 56.67 & 59.08 & 52.475 & 50.808 \\
\hline aramet & $\mathrm{D}$ & 22770 & & & 28.0010 & 12.131 & 10.326 & 16.5663 & 1288 \\
\hline
\end{tabular}

$\begin{array}{lllllllll}\text { Absolute } & .145 & .142 & .150 & .207 & .125 & .144 & .250 & .245\end{array}$

\begin{tabular}{|c|c|c|c|c|c|c|c|c|c|}
\hline \multirow[t]{3}{*}{$\begin{array}{c}\text { Most } \\
\text { Extreme } \\
\text { Differencs }\end{array}$} & & $\begin{array}{c}\mathrm{TK} \\
\text { first }\end{array}$ & $\begin{array}{l}\mathrm{TK} \\
\text { last } \\
\end{array}$ & $\begin{array}{l}\text { LDL } \\
\text { first }\end{array}$ & $\begin{array}{l}\text { LDL } \\
\text { last }\end{array}$ & $\begin{array}{l}\text { HDL } \\
\text { first }\end{array}$ & $\begin{array}{c}\text { HDL } \\
\text { last }\end{array}$ & $\begin{array}{l}\text { TG } \\
\text { first }\end{array}$ & $\begin{array}{l}\mathrm{TG} \\
\text { last }\end{array}$ \\
\hline & Positive & .143 & .134 & .110 & .207 & .125 & .144 & .250 & .245 \\
\hline & Negative & -.145 & -.142 & -.150 & -.116 & -.101 & -.103 & -.120 & -.163 \\
\hline $\begin{array}{c}\text { Kolmogorov } \\
\text { Smirnov Z }\end{array}$ & & .502 & .492 & .518 & .716 & .434 & .498 & .865 & .850 \\
\hline
\end{tabular}


Asymp. Sig. (2-tailed)

Description:

a. Test distribution is Normal.

b. Calculated from data

Based on Table 3, it is known that:

1. Kolmogorov-smirnov value of preliminary TK variable is 0,502 with significance level $0,962>0,05$, thus it has normal distribution.

2. Kolmogorov-smirnov value offinalTK variable is 0,492 with significance level $0,969>0,05$, thus it has normal distribution.

3. Kolmogorov-smirnov value of preliminary LDL variable is 0,518 with significance level $0,951>0,05$, thus it has normal distribution.

4. Kolmogorov-smirnov value offinal LDL variable is 0,716 with significance level $0,684>0,05$, maka berdistribusi normal.

5. Kolmogorov-smirnov value of preliminary HDL variable is 0,434 with significance

level 0,992>0,05, thus it has normal distribution.

6. Kolmogorov-smirnov value offinal HDL variable is 0,498 with significance level $0,965>0,05$, thus it has normal distribution.

7. Kolmogorov-smirnov value of preliminary TG variable is 0,865 with significance level $0,443>0,05$, thus it has normal distribution.

8. Kolmogorov-smirnov value offinal $\mathrm{TG}$ variable is 0,850 with significance level $0,465>0,05$, thus it has normal distribution.

Significance level of $\mathrm{X}_{1}, \mathrm{X}_{2}, \mathrm{X}_{3}, \mathrm{X}_{4}, \mathrm{X}_{5}, \mathrm{X}_{6}$ and $\mathrm{Y}$ variables is $>0,05$, thus data from the four variables are normal distributed.

Table 4. Result of homogeneity test with Chi-Square Test.

\begin{tabular}{|c|c|c|c|c|c|c|c|c|}
\hline & $\begin{array}{l}\text { TK } \\
\text { first }\end{array}$ & $\begin{array}{l}\text { TK } \\
\text { last }\end{array}$ & $\begin{array}{l}\text { LDL } \\
\text { first }\end{array}$ & $\begin{array}{c}\text { LDL } \\
\text { last }\end{array}$ & $\begin{array}{c}\text { HDL } \\
\text { first }\end{array}$ & $\begin{array}{c}\text { HDL } \\
\text { last }\end{array}$ & $\begin{array}{l}\text { TG } \\
\text { first }\end{array}$ & $\begin{array}{l}\text { TG } \\
\text { last }\end{array}$ \\
\hline $\begin{array}{l}\text { Chi- } \\
\text { square }\end{array}$ & $.000^{\mathrm{a}}$ & $.000^{\mathrm{a}}$ & $.000^{\mathrm{a}}$ & $.000^{\mathrm{a}}$ & $1.333^{b}$ & $.000^{\mathrm{a}}$ & $.833^{\mathrm{c}}$ & $1.333^{\mathrm{b}}$ \\
\hline Df & 11 & 11 & 11 & 11 & 9 & 11 & 10 & 9 \\
\hline $\begin{array}{l}\text { Asymp. } \\
\text { Sig. }\end{array}$ & 1.000 & 1.000 & 1.000 & 1.000 & .998 & 1.000 & 1.000 & .998 \\
\hline
\end{tabular}

Description: frequencies less than 5 .

The minimum expected cell frequency is 1.0.

b. 10 cells $(100.0 \%)$ have expected frequencies less than 5 .

The minimum expected cell frequency is 1.2.

c. 11 cells $(100.0 \%)$ have expected frequencies less than 5 .

The minimum expected cell frequency is 1.1.

Based on table 4 it is known that:
1. Chi-Square valueofpreliminary $\mathrm{TK}$ variable is: 0,000 with significance level $1,000>0,05$, thus it is homogenous.'

2. Chi-Square valueoffinal TK variable is; 0,000 with significance level 1,000> 0,05 , thus it is homogenous.

3. Chi-Square valueofpreliminary LDL variable is; 0,000 with significance level $1,000>0,05$, thus it is homogenous.

4. Chi-Square valueoffinal LDL variable is; 0,000 with significance level 1,000> 0,05 , thus it is homogenous. 
5. Chi-Square valueofpreliminary HDL variable is; 1,333 with significance level $0,998>0,05$, thus it is homogenous.

6. Chi-Square valueoffinal HDL variable is; 0,000 with significance level 1,000> 0,05 , thus it is homogenous.

7. Chi-Square valueofpreliminary TG variable is; 0,833 with significance level $1,000>0,05$, thus it is homogenous.

8. Chi-Square valueoffinal TG variable is; 1,333 with significance level 0,988> 0,05 , thus it is homogenous.

Significance level of $\mathrm{X}_{1}, \mathrm{X}_{2}, \mathrm{X}_{3}, \mathrm{X}_{4}, \mathrm{X}_{5}$, $\mathrm{X}_{6}$ and $\mathrm{Y}$ is $>0,05$, it is concluded that data from the seven variables are homogenous.

Hypothesis Test

$t$-test was used for hypotheses testing, establishing the similarity and difference of two average values using two-side test (rightside and left-side tests). The hypotheses tested are as follows:

Ho: $\mu X_{1}: \mu X_{2}=0$

Hi $: \mu X_{1}: \mu X_{2}>0$

Test Criteria: "Accept Ho if $t<\mathrm{t}(1-\alpha)$ and reject Ho if $t$ have any other values. Degrees of freedom for the $t$ distribution is $(\mathrm{n} 1+\mathrm{n} 2$ -

2) with probability (1- $\alpha)$ "(Sudjana, 2005: 238-241).

Hypotheses testing of compared variables:

1. Preliminary testresult ofTotal Cholesterol $\left(\mathrm{KT}_{0}\right)$ : Final test result of Total Cholesterol $\left(\mathrm{KT}_{1}\right)$

$$
\begin{gathered}
\mathrm{H} 0=\mathrm{KT}_{0}: \mathrm{KT}_{1}=<0 \text { insignificant. } \\
\mathrm{H} 1=\mathrm{KT}_{0}: \mathrm{KT}_{1}=>0 \text { significant. } \\
\text { Conclusion }: t \text {-count }=\quad-
\end{gathered}
$$

$>t$ table ${ }_{(11 ; 0.025)}=2,201, \mathrm{H} 0$ is rejected, thus, decrease in total cholesterol after treatment is significant.

2. $\mathrm{HDL}_{0}$ (preliminary test result):

$\mathrm{HDL}_{1}$ (final test result).

$\mathrm{H} 0=\mathrm{HDL}_{0}: \mathrm{HDL}_{1}=<0$ insignificant

$\mathrm{H} 1=\mathrm{HDL}_{0}: \mathrm{HDL}_{1}=>0$ significant

Conclusion: $t$-count $=2,504>\mathrm{t}$ table ${ }_{(11}$; $0.025)=2,201, \mathrm{H} 0$ is rejected, thus increase in $\mathrm{HDL}_{1}$ (after treatment) is significant.

3. $\mathrm{LDL}_{0}: \mathrm{LDL}_{1}$

$\mathrm{H} 0=\mathrm{LDL}_{0}: \mathrm{LDL}_{1}=<0$ insignificant.

$\mathrm{H} 1=\mathrm{LDL}_{0}: \mathrm{LDL}_{1}=>0$ significant.

Conclusion $: t$-count $\quad=\quad-3,764$

$>\mathrm{t}$ table ${ }_{(11 ; 0.025)}=2,201, \mathrm{H} 0$ is rejected, thus, decrease in $\mathrm{LDL}_{1}$ (after treatment) is significant.

4. Triglyceride preliminary test $\left(\mathrm{Tg}_{0}\right)$ :

$\mathrm{Tg}_{1}$ (Triglyceride final test)

$\mathrm{H} 0=\mathrm{Tg}_{0}: \mathrm{Tg}_{1}=<0$ insignificant

$\mathrm{H} 1=\mathrm{Tg}_{0}: \mathrm{Tg}_{1}=>0$ significant.

Conclusion: $t$-count $=-1,605<\mathrm{t}$ table ${ }_{(11}$; $0.025)=2,201, H_{0}$ is accepted, thus decrease in Triglyceride after treatment is insignificant.

Complete analysis of the results can be seen in the following graph below.

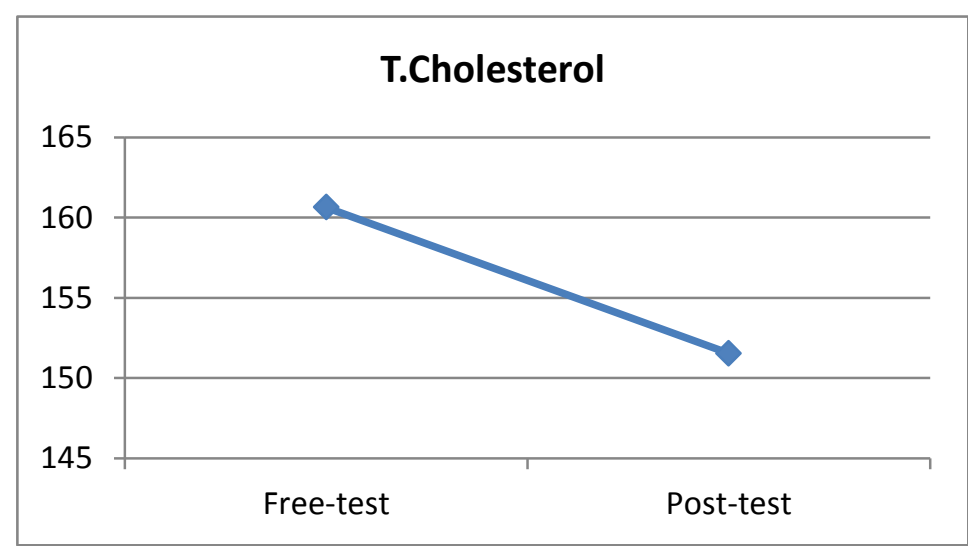

a. Graph of changes total cholesterol before and after the Bleep-Test. 


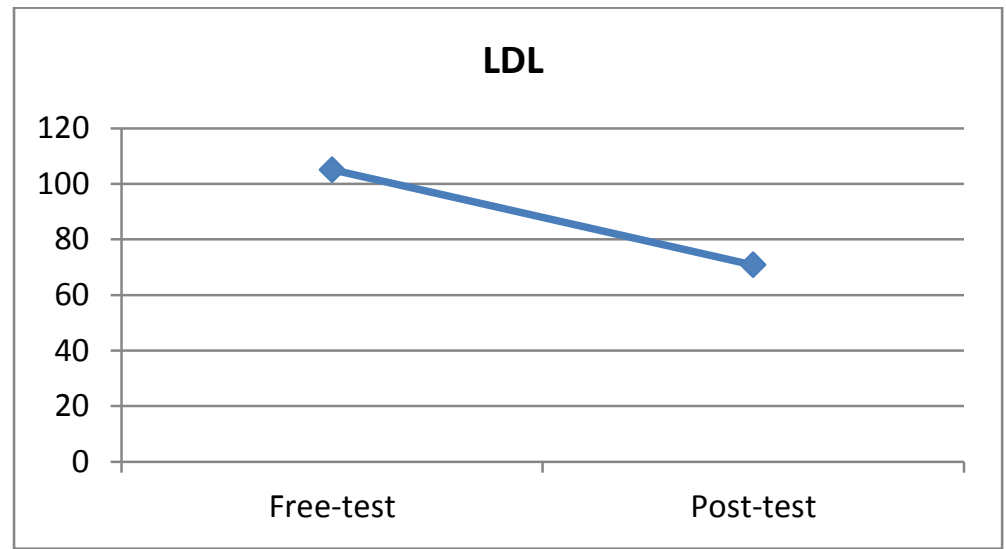

b. Graph of changes triglisride before and after the Bleep-Test.

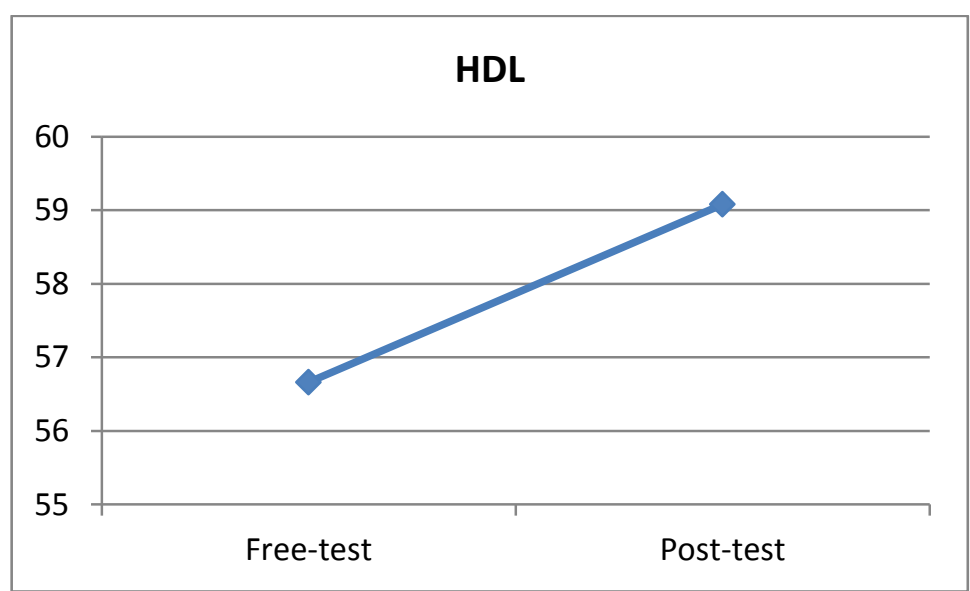

c. Graph of changes HDL before and after the Bleep-Test.

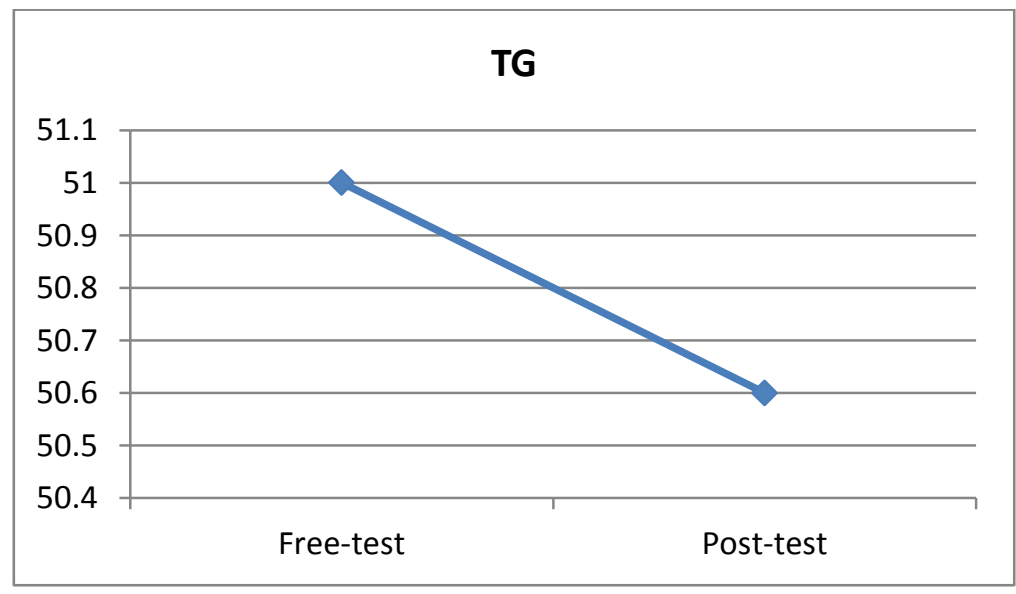

d. Graph of changes triglisride before and after the Bleep-Test. 


\section{DISCUSSION}

This study used both normality and homogeneity tests. The results indicate that research samples are in normal distribution where homogeneity analysis result in homogenous conclusion. Thus, the conditions of analysis were met and may proceed to hypothesis testing.

The study results showed a significant decrease in total cholesterol, and high density lipoprotein (HDL) increased significantly immediately after the attainment of maximum aerobic capacity of the subjects. Using standard examination (clinical test) showed that low density lipoprotein (LDL) level was decreased significantly. Changes in triglyceride variable showed no significant decrease although statistically differ, shown in smaller average value of triglyceride final test results (after treatment). Thus, in this study, aerobic exercise shown by measurements using maximum aerobic capacity, is not only dramatically alters cholesterol level but also become significant due to the favorable changes in the distribution of lipoprotein sub-class.

The above mentioned specific sub-class is similar to increased HDL and decreased LDL after exercise. It is known that HDL is a favorable lipoprotein sub-class for the body whereas LDL is not. Therefore, significant increase in HDL and decrease in LDL in this study appear advantageous to the body which consequently alter the risk of coronary heart disease due to one of HDL functions is to eliminate LDL from the blood vessels.

The results of this study also showed that trained individuals in endurance exercise intensity or during measurement of their maximum aerobic capacity will have higher fat oxidation. The increase in fat oxidation induced by exercise is (mainly) due to increased fatty acid oxidation. Fat oxidation is lower in high-intensity exercise compared to moderate-intensity. This is partly due to the decreasing fatty acid transfer to the working muscles.

Despite no significant decrease in the triglyceride variable, the measurement was statistically differ (Tables 1 and 2), such as the lower mean value of triglyceride final test results (after treatment). Other studies showed a decrease in blood triglyceride level. Harry H. Yu, Geoffrey S. Ginsburg, Mary L. O'Toole, James D. Otvos, Pamela S. Douglas, Nader Rifai (1999), shown that the decrease was quite obvious due to increasing fatty acid metabolism related to the duration of exercise or race. Thus, aerobic activity in those studies was positively correlated with the duration of exercise. This study shows a decrease in mean value and statistically insignificant, indicates that duration of exercise (on aerobic capacity measurement) is not acutely affected the triglyceride level. If the objective is the decrease in blood triglyceride level, the bleep test (to measure $\mathrm{VO}_{2} \max$ ) may not correlate with the expected decrease. This requires further study, because it has been known that base level of triglyceride serum found to be lower in endurance athletes.

\section{CONCLUSION}

Based on data analysis and discussion in this study, the conclusion is drawn as follows:

Blood cholesterol profile after the measurement of maximum oxygen capacity $\left(\mathrm{VO}_{2} \max \right)$ has better value than before.

\section{REFERENCES}

Chen KT, Yang RS, 2004. Effects of Execise on Lipid Metabolism and Musculoskeletal Fitness in Female Athletes, Word Journal of Gastroenterology, 10 (1):122-126.

Despopoulos A, Silbernagl S, 1998. Fisiologi, edisi 4 (alih bahasa: dr. Yurita Handoyo), Hipokrates, Jakarta. Hal., 222-258.

Dowling EA, 2001. How Exercise Affects Lipid Profiles in Women, The Physician And Sportmedicine, 29 (9):45-50. 
Fox EL, Bowers R, Foss ML, 1993. The Physiological Basis Of Exercise and Sport, $5^{\text {th }}$ edition. WBC Brown \& Benchmark, Iowa. pp 375; 387; 410.

Harry H. Yu, Geoffrey S. Ginsburg,Mary L. O'Toole, James D. Otvos, Pamela S. Douglas, Nader Rifai.1999.Acut Changes in Serum Lipid and Lipoprotein Subclasses in Triathletes as Assessed by Proton Nuclear Magnetic Resonance Spectroscopy,Artheriocler Thromb Vas Biol.19:1945-1949.

Jefrey F Horowitz and Samuel Klein. 2000.Lipid Metabolism During Endurance Exercise.Am J Clin Nutr.72(suppl):558S63S.

Shadiqin AR, 2001.Pengaruh Latihan Aerobik Intensif Interval Terhadap Respons Imun di Titik Defleksi Denyut Nadi, Program Pascasarjana, Unair-Surabaya, Hal.,7-12; 56.

Soeharto I, 2002. Kolesterol \& Lemak Jahat Kolesterol \& Lemak Baik, PT.Gramedia Pustaka Utama, Jakarta. Hal., 83; 108; 233.

Suryabrata S, 2003. Metode Penelitian, (Divisi Buku Perguruan Tinggi) PT.RajaGrafindo Persada, Jakarta, Hal.,100-109

Vander AJ, Sherman JH, Luciano DS, 2001. Human Physiology, $8^{\text {th }}$ edition. New York: McGraw-Hill Book Co., pp 41; 267-270; 312-324; 610-612.

Vella CA, Kravitz L, Janot JM, 2003. A Review of The Impact of Exercise on Cholesterol Levels, www// webmaster @hkusa.com. 